\title{
Why Bangladeshi Higher Educational Institutions Should Introduce Community Economic Development as a New Field of Study: Some Suggestions
}

\author{
Mohamed K Haq ${ }^{1}$, Saleh Md Arman ${ }^{2}$, Farzana Nazera ${ }^{3}$

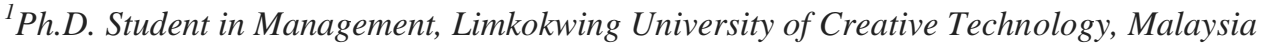 \\ Former Lecturer, Department of Management, University of Dhaka, Bangladesh \\ ${ }^{2}$ MSc in Sustainable Development, Uppsala University \\ Researcher in Circular Economy and Community Economic Development \\ Assistant Professor (on leave), RP Shaha University, Bangladesh \\ ${ }^{3}$ Ph.D. Student in Management, Limkokwing University of Creative Technology, Malaysia
}

\begin{abstract}
Community Economic Development (CED) is a popular field of study in the top North American universities. But, this field of study is completely absent in Bangladesh, even not a single course has been found in their course curricula based on their websites. Some courses are under development studies but those are insufficient compared to the required courses offered in foreign universities. Interestingly, CED approach is a countrywide approach practiced by NGOs, specialized bank and corporate houses of Bangladesh. CED approach is highly associated with sustainable development by fulfilling numerous goals successfully. The study aims at to develop urgency of the concerned stakeholders of the higher educational institutions of Bangladesh to design, implement and execute program and courses on CED in order to make the country sustainable and in doing so the paper showed CED professions in Bangladesh and in the world, which considered pragmatic in CED course at the university level. The study considered different CED study programs and courses offered by reputed universities of the world including reasons behind introducing the program in their course curriculum and expected benefits derived from the courses. The paper finally suggests ways of implementing it at the university level of Bangladesh. The study makes the concerned stakeholders aware about CED programs and courses for successful development, implementation and execution.
\end{abstract}

Keywords: Community Economic Development (CED), Sustainable Development, Course Design, University.

\section{INTRODUCTION AND PROBLEM BACKGROUND}

$\mathrm{T}$ discipline of studying Community Economic 1 Development (CED) is quite popular in Canada and there are numerous bachelors, master, diploma and professional certificate courses offered by many Canadian universities. Also, couple of US universities, including Harvard University, offers such courses. Many European universities offer separate Community Development and Economic Development courses. Same scenario observes in Asian and African Universities.
Bangladesh is a densely populated country in South Asia. It has a great history in community economic development through the invention of micro finance of Grameen Bank and establishment of the world's largest NGO BRAC to develop sustainable community economic development of Bangladesh (The Borgen Project, 2018; Islam, 2015; Hassan and RenteriaGuerrero, 1997). Moreover, many business organizations contribute in the Community Economic Development aspects by promoting different types of contract farming initiatives (Haq, Arman and Nazera, 2021). In this aspect, educational practice is important to make this discipline more updated and upgraded.

According to the University Grants Commissions of Bangladesh (UGC), there are 46 public universities and 107 private universities (UGC, 2021). The study searched each of their websites to find out whether any of those universities offer such course, but none of them have any such courses which offer either any form of Community Economic Development (CED) courses in their existing curriculum.

The study would like to revisit the concept of Community Economic Development (CED), its contribution in Bangladesh, existing academic offerings of CED all over the world and suggestion about to design academic offerings in Bangladesh perspective.

\subsection{Problem Statement}

Despite having a good contributory history by NGOs (Islam, 2015), specialized banks (Hassan and Renteria-Guerrero, 1997) and corporate houses (Haq, Arman and Nazera, 2021) in Community Economic Development of Bangladesh, there are no such course or academic program offered by any university of Bangladesh which creates knowledge gap for people. Suitable course design, implementation and execution are important for carrying out this discipline more efficiently and effectively. 


\subsection{Research Gap and Originality of the Study}

There is no study available on assessing the importance of studying CED at the university level of Bangladesh. Also, there is no published paper or policy paper available on designing, implementing and executing such program and course at the university level. Considering those gaps, the study is an exploratory in nature which would discuss about CED courses in Bangladeshi university perspective, set model derived from reputed foreign universities and suggest the concerned stakeholders about CED programs and courses.

\subsection{Aim and Scope}

This study aims to point out the importance of academic programs and courses on Community Economic Development (CED) in Bangladeshi perspective by discussing its importance and contribution in the country's sustainable community economic development. The study would consider the higher educational institutions, that is, university as the unit of analysis. Non university educational institutions are not considered in this study.

\subsection{Research Questions}

The study has the following research questions:

RQ1: Why studying CED at the university level is important in Bangladesh?

RQ2: How to develop, implement and execute CED programs and courses at the university level?

RQ3: What would be tentative roles of stakeholders in order to develop, implement and execute CED programs and courses at the university level?

\subsection{Objectives of the study}

In line with the research questions above, the study seeks the following objectives.

1. Assess the importance of studying CED at the university level of Bangladesh.

2. Design, implement and execute proposed university level CED programs and courses of Bangladesh.

3. Role of concerned stakeholders in the proposed university level CED programs and courses of Bangladesh.

\section{METHODOLOGY OF THE STUDY}

The study is purely depending on secondary sources of literatures. University information provided on their websites are the only source of data collection. Researchers searched on google to find out courses on Community Economic Development in different foreign universities. Other literatures considered from reliable website and scholarly articles available at google scholar. The study considered those course designs as a model of executing future course line of CED programs and course materials of different course offerings at the bachelor, diploma, master and professional certification programs. The study designed a model of proposed university level CED programs and courses applicable to Bangladesh.

\subsection{Delimitation and Ethical Consideration}

Researchers didn't come across with any concerned university official while collecting information about the study programs and courses of any Bangladesh or foreign university. Only the website information considered reliable in this aspect.

\section{CONCEPT OF COMMUNITY ECONOMIC DEVELOPMENT (CED)}

Community economic development (CED) is a multidisciplinary approach which covers all sorts of relevant community and economic aspects and promotes the development as a whole. Renowned scholars have contributed in this area to make it more updated and upgraded as the time passed. Boothroyd and Davis (1993) stated first about the concept of CED in their publication which mention about such a discipline which discussed about growth, structural change and community relationships. They tell CED is a system of human activity directed to meeting human wants that is determined by deliberate allocations of scarce resources based on four vital assumptions: i) the local economy extends beyond marketplace transactions through non-cash transaction in order to promote wellbeing of the society, ii) increase local control, iii) local and diversified ownership, local resource control, diversification of exports, and import replacement are the keys of monetary flow of the community, and iv) deliberate restructuring of the local economy by people of the concerned community (ibid).

Weissbourd and Bodini (2005) mentioned four aspects of CED based on market driven approach: i) Proper identification of poverty and creation of wealth, ii) Asset investment is the approach to resolve poverty of the society, iii) Market is the mechanism of asset investment, iv) market activity and wealth maximization are positively correlated.

According to Shaffer, Deller and Marcouiller (2006), CED is a combination of community development and economic development and an interdisciplinary and holistic approach to ensure the economic sustainability of the people of the community through 6 paradigms: space, decision making, rules/ institutions, resources, society/culture and markets. As per their insights, community economic development occurs when people in a community analyze the economic conditions of that community, determine its economic needs and unfulfilled opportunities, decide what can be done to improve economic conditions in that community, and then move to achieve agreed-upon economic goals and objectives.

Phillips and Pittman (2009) considered CED as a combination of Community Development and Economic Development and the purpose of community development is to produce assets and the purpose of economic development is to mobilise those assets. They mentioned four types of capitals which are the keys to community economic development: human, financial, physical and social capitals. 


\subsection{Importance of Community Economic Development} Courses at the University Level:

Significant importance on the knowledge and application to the CED approaches is important to make the society sustainable and self-sufficient. Phillips and Pittman (2009) distinguished two types of CED professionals who are the keys of CED implementation in the society. The classification is given below in a diagram:

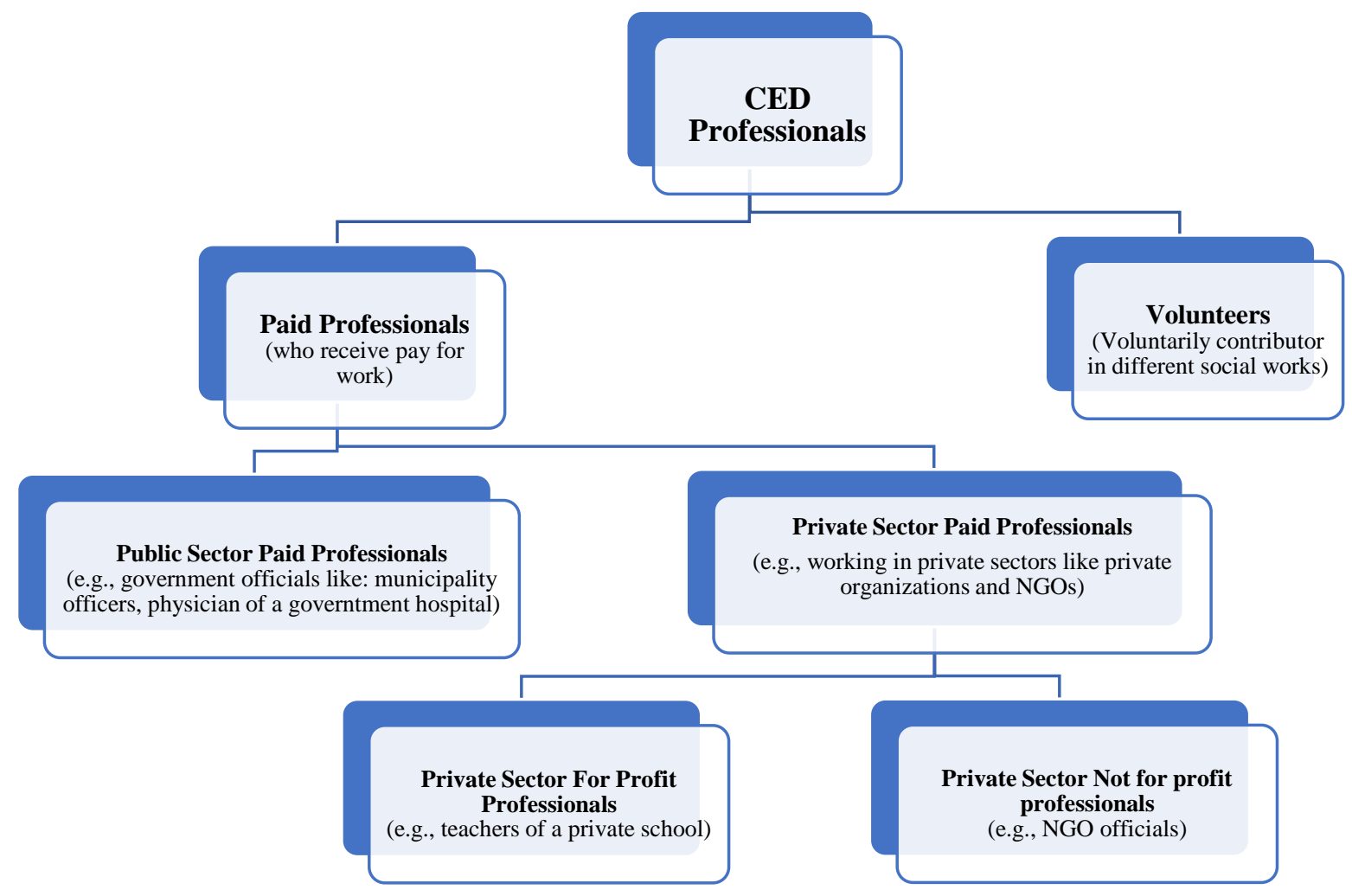

Figure 1: Classification of CED professional

(The diagram is prepared according to CED professional discussion by Phillips and Pittman (2009)

From the diagram, it has been seen that, all types of professionals are involved under the category of CED professionals. Their own uniform and unique contributions are a collective effort to the sustainable development of the community economic situation of a country. So, the knowledge of CED approach is important to know for all professionals in a society. CED courses offered by reputed universities in the world are doing such vital contribution. In line with this aspect of holistic and multidisciplinary approach and contribution, it is also important to introduce CED courses in Bangladeshi higher educational institutions.

\subsection{Importance of CED Courses in Bangladesh Perspective:}

According to Haq, Arman and Nazera (2021), Bangladesh has a great contribution to community economic development through contract farming of different industries, for example poultry industry which has a positive change in the rural community of Bangladesh. Moreover, the CED professional lists discussed in the previous section provided by Phillips and Pittman (2009) resembles perfectly in Bangladesh perspective. These sectors are available in Bangladesh and lots of people are involving, directly and indirectly, under those professionals' category. For example, NGOs are the main players in CED sectors of Bangladesh These CED professionals arrive from different disciplines and none of them haven't got the opportunity to learn specialized CED knowledge. According to Rottinghouse and Borgen (2005), Lehker and Furlong (2006) and Lawson and Myers (2011), career related degrees in any field accelerate career success and help people to contribute more in the respective fields. In line with these contributions from the researchers, it can be said that, CED professionals need to grab academic degrees as academic studies are linked to collective norms, values and relationships reflecting the involvement of human individuals in 'a common life based on family and community (McClenaghan, 2000). CED professionals, engaging in different sectors of Bangladesh, is important to know the sustainable contribution in the community and economic development of Bangladesh, especially in the rural areas, in order to make the country sustainable (Gazi, 2007). According to Hussain et al. (2015), sustainable community economic development of Bangladesh has a great prospect in terms of academic literature, country and economic aspects in order to develop a production system without destroying environment, economic growth as well as employment, ensure stable living, encourage energy use from renewable resources 
and increase currency flowing within communities. They argued that, to ensure these aspects, Bangladesh needs consultancy and technical support and training facilities. These facilities can be provided by the higher educational institutions of Bangladesh.

\section{RESULT AND DISCUSSION}

\subsection{Reasons Behind CED Courses and Expected Derived Benefits:}

By nature, CED courses are multidisciplinary and all sorts of students are getting welcomed by the universities in taking admission. The listed foreign universities introduce CED courses for various reasons and produce different positive impacts for the society, community and economy at large. According to their websites, they mention different reasons of introducing CED courses which are as follows:

1. Understanding of the theory and applications of stateof-the-art community and economic development tools and methods.

2. Assessing the evolution of community economic development, community organizing and different theories of economic change.

3. Establishing and maintaining viable communities and community organizations.

4. Enhancing the quality of life in communities in responsible, sustainable, cost-effective ways.

5. Focusing community development in strategic visioning, volunteer management, place-making and environmental sustainability.

6. Focusing economic development in business retention and expansion, entrepreneurial ecosystem development and business site location.

7. Focusing data management through conducting surveys and focus groups, digital marketing and community economic analysis

8. Assessing community-based social and economic transformation and social innovation.

9. Diversity in terms of different demographic aspects, e.g., age, gender, race.

Participants are expected to be benefitted derived from the CED courses are as follows:

- Problem-solving and analytical skills in community development, economic development and data management.

- Interpersonal and communication skills

- Understanding of community economic development and business

- Leadership roles in the private, public and community sectors.

- Entrepreneurial skills in starting own CED ventures.

- Sustainable change agent of the community.

- Careers in various community organizations, including anti-poverty, urban and housing development, women's rights, and immigration.

\subsection{Existing CED Program offered in the world:}

From the discussion above, it has been proved that, CED knowledge and application is pragmatic to ensure proper implementation and realization of the true meaning and benefit of CED. In order to address this issue, reputed universities of the world offer different programs and courses. Most of them are master level programs, like, Master of Arts, Master of Business Administration and so on. The study searched on google mentioning "Courses of Community Economic Development". For better accuracy, the study searched in mastersportal.com and 2097 masters' course appeared. For bachelor course, the study searched at bachelorsportal.com and 3266 bachelor's degree appeared. Based on screening, the study selected the, most relevant courses offered by the reputed universities and most of them are located in the USA and Canada.

Table 1: University, Programme Name, Duration and Mode of Delivery ${ }^{1}$

\begin{tabular}{|c|c|c|c|}
\hline University & Programme Name & Credit & Duration \\
\hline $\begin{array}{l}\text { Massachusetts } \\
\text { Institute of } \\
\text { Technology } \\
\text { (MIT) }\end{array}$ & $\begin{array}{l}\text { Introduction to } \\
\text { Housing, } \\
\text { Community, and } \\
\text { Economic } \\
\text { Development }\end{array}$ & 3 & 1 month \\
\hline $\begin{array}{l}\text { The Pennsylvania } \\
\text { State University } \\
\text { (PSU) }\end{array}$ & $\begin{array}{c}\text { Master of Professional } \\
\text { Studies Degree in } \\
\text { Community and } \\
\text { Economic } \\
\text { Development } \\
\text { (CEDEV) }\end{array}$ & 30 & $\begin{array}{l}\text { Flexible/ } \\
\text { Online }\end{array}$ \\
\hline $\begin{array}{l}\text { South Dakota } \\
\text { State University } \\
\text { (SDSU) }\end{array}$ & $\begin{array}{c}\text { Certificate in Native } \\
\text { Community and } \\
\text { Economic } \\
\text { Development }\end{array}$ & 12 & $\begin{array}{l}\text { Flexible/ } \\
\text { Online }\end{array}$ \\
\hline $\begin{array}{l}\text { South Dakota } \\
\text { State University } \\
\text { (SDSU) }\end{array}$ & $\begin{array}{c}\text { Certificate in } \\
\text { Community } \\
\text { Development }\end{array}$ & 06 & $\begin{array}{l}\text { Flexible/ } \\
\text { Online }\end{array}$ \\
\hline $\begin{array}{c}\text { The Pennsylvania } \\
\text { State University } \\
\text { (PSU) }\end{array}$ & $\begin{array}{c}\text { Graduate Certificate in } \\
\text { Community and } \\
\text { Economic } \\
\text { Development }\end{array}$ & 15 & $\begin{array}{c}15 \text { Weeks } \\
\text { Online }\end{array}$ \\
\hline $\begin{array}{l}\text { Kansas State } \\
\text { University (K- } \\
\text { State) }\end{array}$ & $\begin{array}{c}\text { Community } \\
\text { Development Graduate } \\
\text { Certificate }\end{array}$ & 15 & $\begin{array}{l}\text { Flexible/ } \\
\text { Online }\end{array}$ \\
\hline $\begin{array}{l}\text { Kansas State } \\
\text { University (K- } \\
\text { State) }\end{array}$ & $\begin{array}{c}\text { Community } \\
\text { Development Master's } \\
\text { Degree }\end{array}$ & 30 & $\begin{array}{l}\text { Flexible/ } \\
\text { Online }\end{array}$ \\
\hline $\begin{array}{c}\text { Akamai } \\
\text { University (Aku) }\end{array}$ & $\begin{array}{c}\text { Master of Science in } \\
\text { Community and } \\
\text { Economic } \\
\text { Development }\end{array}$ & 40 & $1-4$ Year \\
\hline $\begin{array}{c}\text { Victoria } \\
\text { University, } \\
\text { Australia (VU) }\end{array}$ & $\begin{array}{c}\text { Master of International } \\
\text { Community } \\
\text { Development } \\
\end{array}$ & 192 & 2 Years \\
\hline $\begin{array}{c}\text { Utah State } \\
\text { University (USU) }\end{array}$ & $\begin{array}{c}\text { Regional and } \\
\text { Community Economic } \\
\text { Development }\end{array}$ & 3 & \\
\hline
\end{tabular}

\footnotetext{
${ }^{1}$ Most of the universities offer Sustainable Development, Economics, Micro Economics, Macro Economics, Management, HRM, Seminar and workshop courses, and Communication Skills in their course curriculum.
} 


\begin{tabular}{|c|c|c|c|}
\hline $\begin{array}{c}\text { University of } \\
\text { Central Arkansas }\end{array}$ & $\begin{array}{c}\text { Masters of Science in } \\
\text { Community and } \\
\text { Economic } \\
\text { Development } \\
\text { (MSCED) }\end{array}$ & 36 & Online \\
\hline $\begin{array}{c}\text { Cape Breton } \\
\text { University (CBU), } \\
\text { Canada }\end{array}$ & $\begin{array}{c}\text { Master of Business } \\
\text { Administration in } \\
\text { Community Economic } \\
\text { Development }^{2} \\
\end{array}$ & & 1-2 Year \\
\hline $\begin{array}{c}\text { Concordia } \\
\text { University, } \\
\text { Canada }(\mathrm{CU})\end{array}$ & $\begin{array}{c}\text { Graduate Diploma in } \\
\text { Community } \\
\text { Economic } \\
\text { Development }\end{array}$ & 30 & 1-2 Year \\
\hline $\begin{array}{c}\text { The Open } \\
\text { University of } \\
\text { Tanzania (OUT) }\end{array}$ & $\begin{array}{c}\text { Bachelor of } \\
\text { Community Economic } \\
\text { Development (BCED) }{ }^{3}\end{array}$ & 40 Units & 3 Levels \\
\hline $\begin{array}{l}\text { Western Illinois } \\
\text { University (WIU) }\end{array}$ & $\begin{array}{l}\text { Master of Arts Degree } \\
\text { in Community and } \\
\text { Economic } \\
\text { Development (CED) }\end{array}$ & 36 & 17 Months \\
\hline $\begin{array}{l}\text { Suny Empire State } \\
\text { College (SESC) }\end{array}$ & $\begin{array}{l}\text { Master of Arts in } \\
\text { Community and } \\
\text { Economic } \\
\text { Development }\end{array}$ & 36 & Flexible \\
\hline $\begin{array}{l}\text { Suny Empire State } \\
\text { College (SESC) }\end{array}$ & $\begin{array}{l}\text { M.A. In Community } \\
\text { and Economic } \\
\text { Development } \\
\text { Advanced Certificate } \\
\text { Options } \\
\end{array}$ & 48 & Flexible \\
\hline $\begin{array}{l}\text { Illinois Institute of } \\
\text { Technology (IIT) }\end{array}$ & $\begin{array}{c}\text { Bachelor of Science in } \\
\text { Social and Economic } \\
\text { Development Policy } \\
\text { (SEDP) }\end{array}$ & 48 & 4 YEARS \\
\hline $\begin{array}{c}\text { The University Of } \\
\text { North Carolina At } \\
\text { Chapel Hill } \\
\text { (UNCCH) }\end{array}$ & $\begin{array}{l}\text { Master of Public } \\
\text { Administration in } \\
\text { Community and } \\
\text { Economic } \\
\text { Development }\end{array}$ & 45 & $\begin{array}{l}18 \text { Months } \\
\text { To } 5 \text { Year }\end{array}$ \\
\hline $\begin{array}{c}\text { University } \\
\text { College of The } \\
\text { North, Canada } \\
\text { (UCN) } \\
\end{array}$ & $\begin{array}{c}\text { Diploma in } \\
\text { Community Economic } \\
\text { Development }\end{array}$ & N/A & 2 YEAR \\
\hline $\begin{array}{l}\text { Illinois State } \\
\text { University (ISU) }\end{array}$ & $\begin{array}{c}\text { Master in Applied } \\
\text { Community and } \\
\text { Economic } \\
\text { Development (ACED) }\end{array}$ & 34 & Flexible \\
\hline $\begin{array}{c}\text { Ryerson } \\
\text { University, } \\
\text { Canada (RU) } \\
\end{array}$ & $\begin{array}{c}\text { Certificate in Local } \\
\text { Economic } \\
\text { Development (LED) }\end{array}$ & 4 Courses & Flexible \\
\hline $\begin{array}{c}\text { Harvard Kennedy } \\
\text { School, Harvard } \\
\text { University (HKS- } \\
\text { HU) } \\
\end{array}$ & $\begin{array}{l}\text { Executive Certificate } \\
\text { in Economic } \\
\text { Development }\end{array}$ & 8 Courses & Flexible \\
\hline $\begin{array}{c}\text { University of } \\
\text { Waterloo (UW) }\end{array}$ & $\begin{array}{c}\text { Certificate in } \\
\text { Economic } \\
\text { Development }\end{array}$ & 2 Courses & 2 Year \\
\hline $\begin{array}{l}\text { University of New } \\
\text { Hampshire (UNH) }\end{array}$ & $\begin{array}{c}\text { Community } \\
\text { Development Policy } \\
\text { and Practice (M.A.) }\end{array}$ & 36 Credits & 14 months \\
\hline $\begin{array}{c}\text { Murdoch } \\
\text { University, } \\
\text { Australia (MU) }\end{array}$ & $\begin{array}{l}\text { Master of Community } \\
\text { Development }\end{array}$ & 48 credits & 2 year \\
\hline $\begin{array}{c}\text { Ritsumeikan } \\
\text { University, Japan, } \\
\text { (RMU) }\end{array}$ & $\begin{array}{l}\text { Master's Program in } \\
\text { Economic } \\
\text { Development }\end{array}$ & 30 credits & 2 year \\
\hline
\end{tabular}

${ }^{2}$ They mostly offer business related courses.

${ }^{3}$ Except internship and field study, no core and elective course offered related to CED. For more info, see: https://www.out.ac.tz/bced/

\begin{tabular}{|c|c|c|c|}
\hline $\begin{array}{c}\text { Great Plains } \\
\text { College, Canada } \\
(\text { GPC })^{4}\end{array}$ & $\begin{array}{c}\text { Master of Business } \\
\text { Administration In } \\
\text { Community Economic } \\
\text { Development }\end{array}$ & Variable & 2 Years \\
\hline
\end{tabular}

Source: Compilation by authors

From the programs discussed in Table 2, the study makes a comprehensive list of course offerings which are given below.

Table 2: Course Title and Offered Universities

\begin{tabular}{|c|c|}
\hline $\begin{array}{c}\text { Principles of Local Economic } \\
\text { Development }\end{array}$ & PSU, RU, SDSU \\
\hline $\begin{array}{c}\text { Community Structure, Processes } \\
\text { and Capacity }\end{array}$ & PSU \\
\hline $\begin{array}{l}\text { Community Development Project } \\
\text { planning and management }\end{array}$ & VU \\
\hline $\begin{array}{l}\text { Introduction to/ Fundamentals of } \\
\text { Community and Economic } \\
\text { Development: Theory and Practice }\end{array}$ & $\begin{array}{c}\text { PSU, UCA, CU, SESC, UCN, } \\
\text { RU, UW }\end{array}$ \\
\hline Community Development Policy & $\begin{array}{c}\text { UCA, CU, SESC, SDSU, } \\
\text { UNH, MU } \\
\end{array}$ \\
\hline Native CED (4 COURSES) & SDSU \\
\hline CED Model & $\mathrm{CU}$ \\
\hline Leadership Development IN CED & PSU, AkU, VU, UCA, WIU \\
\hline $\begin{array}{c}\text { Economic Development } \\
\text { Management }\end{array}$ & $\begin{array}{c}\text { VU, UCA, WIU, UNCCH, } \\
\text { RU, UNH }\end{array}$ \\
\hline $\begin{array}{l}\text { Population, Land Use and } \\
\text { Municipal Finance }\end{array}$ & PSU \\
\hline Community Organizing and CED & CU, SESC \\
\hline $\begin{array}{c}\text { Methods and Techniques for } \\
\text { Community and Economic } \\
\text { Development }\end{array}$ & PSU, CU, IIT \\
\hline Research on CED & $\begin{array}{l}\text { PSU, K-State,VU,AkU, UCA, } \\
\text { CBU, CU,OUT, WIU, SESC, } \\
\text { IIT, UNCCH, UCN, RU }\end{array}$ \\
\hline $\begin{array}{c}\text { Financing in Economic } \\
\text { Development }\end{array}$ & HKS-HU, UNH \\
\hline Economic Development & $\begin{array}{c}\text { HKS-HU, UW, UNH, PSU, } \\
\text { MU }\end{array}$ \\
\hline INTERNSHIP & $\begin{array}{l}\text { PSU, K-State,VU,AkU, UCA, } \\
\text { CBU,CU, OUT, WIU, SESC, } \\
\text { IIT, UNCCH, UCN, MU }\end{array}$ \\
\hline Field Study & $\begin{array}{c}\text { PSU, K-State,VU,AkU, UCA, } \\
\text { CBU,CU, OUT, WIU, IIT, } \\
\text { UNCCH, UCN, MU }\end{array}$ \\
\hline Statistics & $\begin{array}{l}\text { PSU, OUT, UNCCH, SESC, } \\
\text { IIT, UCN }\end{array}$ \\
\hline $\begin{array}{c}\text { Regional Development: Principles, } \\
\text { Policy, and Practice: }\end{array}$ & PSU, IIT \\
\hline $\begin{array}{l}\text { Resilient Communities and } \\
\text { Environments: }\end{array}$ & PSU \\
\hline $\begin{array}{l}\text { Entrepreneurship in the } \\
\text { Community: }\end{array}$ & PSU, CU \\
\hline $\begin{array}{l}\text { Community Ventures, Nonprofits, } \\
\text { and Organizations: }\end{array}$ & PSU, K-State, UNCCH \\
\hline $\begin{array}{l}\text { Principles and Practices of } \\
\text { Planning CED venture }\end{array}$ & PSU, UCN \\
\hline $\begin{array}{l}\text { Theories, Principles, and } \\
\text { Institutions of International } \\
\text { Development: }\end{array}$ & PSU, IIT, UNCCH \\
\hline $\begin{array}{l}\text { Principles and Strategies of } \\
\text { Community Change }\end{array}$ & K-State, UCN \\
\hline
\end{tabular}

${ }^{4}$ They offer business courses in CED approach. For more information, see their website: https://www.greatplainscollege.ca/sites/default/files/202011/MBA\%20CED_WarmanBookletSEP2020.pdf 


\begin{tabular}{|c|c|}
\hline Organizing for Community Change & K-State \\
\hline Community Analysis & K-State \\
\hline $\begin{array}{l}\text { Community and Regional } \\
\text { Economic Analysis }\end{array}$ & K-State \\
\hline $\begin{array}{c}\text { Community and Natural Resource } \\
\text { Management }\end{array}$ & K-State \\
\hline $\begin{array}{c}\text { Orientation to Community } \\
\text { Development }\end{array}$ & K-State \\
\hline Sustainable Communities & K-State \\
\hline $\begin{array}{c}\text { Ecological Economics, } \\
\text { Environmental (RMU) Economics }\end{array}$ & K-State, RMU \\
\hline $\begin{array}{l}\text { Community Leadership and } \\
\text { Capacity Building }\end{array}$ & K-State, VU \\
\hline Grant writing & K-State, UCA, IIT, UNCCH \\
\hline Proposal Writing & K-State \\
\hline Immigrants in Communities & K-State \\
\hline $\begin{array}{l}\text { Economic Development Strategies } \\
\text { and Programs } \\
\end{array}$ & K-State, AkU \\
\hline Land Development Planning & K-State \\
\hline Applied Community Development & K-State \\
\hline Introduction to GIS & K-State, UCA, IIT \\
\hline $\begin{array}{l}\text { Mapping Fundamentals and } \\
\text { Modeling for CED in planning and } \\
\text { project through GIS ( } 5 \text { courses at } \\
\text { UCA) }\end{array}$ & UCA, IIT \\
\hline Climate Change & HKS-HU, UCA, K-State, IIT \\
\hline History of Global Development & $\mathrm{AkU}, \mathrm{MU}$ \\
\hline Globalization and Development & $\mathrm{AkU}$ \\
\hline $\begin{array}{c}\text { Growth in Underdeveloped } \\
\text { Countries }\end{array}$ & $\mathrm{AkU}$ \\
\hline Poverty Reduction Models & $\mathrm{AkU}$ \\
\hline Environmental Impact Assessment & $\mathrm{AkU}, \mathrm{VU}$ \\
\hline Social Impacts of Development & $\mathrm{AkU}, \mathrm{UNH}$ \\
\hline $\begin{array}{c}\text { Transnational Gender Issues and } \\
\text { Human Rights }\end{array}$ & VU \\
\hline $\begin{array}{l}\text { Management in Non-Government } \\
\text { Organisations }\end{array}$ & $\mathrm{AkU}, \mathrm{VU}$ \\
\hline $\begin{array}{c}\text { Engaging Communities for } \\
\text { Sustainability }\end{array}$ & VU \\
\hline $\begin{array}{l}\text { Conflict Resolution in Groups and } \\
\text { Communities }\end{array}$ & VU, MU \\
\hline Planetary Health & VU \\
\hline Disaster Resilience and Response & VU \\
\hline Responding to Climate Change & VU \\
\hline $\begin{array}{c}\text { Regional and International } \\
\text { Organisations and Policy }\end{array}$ & VU \\
\hline $\begin{array}{c}\text { Economic and Industrial } \\
\text { Development }\end{array}$ & UCA, CBU, MU \\
\hline $\begin{array}{l}\text { International Development and } \\
\text { CED: }\end{array}$ & $\mathrm{CU}$ \\
\hline Aboriginal CED & $\mathrm{CU}, \mathrm{VU}$ \\
\hline Indigenous Community & MU \\
\hline $\begin{array}{l}\text { Woman and Economic } \\
\text { Development }\end{array}$ & HKS-HU, \\
\hline $\begin{array}{c}\text { Principles of Community } \\
\text { Development }\end{array}$ & WIU, MU \\
\hline $\begin{array}{c}\text { Advanced Community } \\
\text { Development Theory and Practice }\end{array}$ & WIU, MU \\
\hline
\end{tabular}

\begin{tabular}{|c|c|}
\hline $\begin{array}{c}\text { Cultural Geography: Rural } \\
\text { Development }\end{array}$ & WIU \\
\hline $\begin{array}{c}\text { Sustainability and Community } \\
\text { Economic Development }\end{array}$ & WIU \\
\hline Non-metro Planning & WIU \\
\hline Ethical Issues in Social Policy & SESC \\
\hline Democracy, Dictator, \& Develop & IIT \\
\hline Public Service Leadership & UNCCH. HKS-HU \\
\hline $\begin{array}{c}\text { Public Administration and } \\
\text { evaluation (3 courses at UNCCH) }\end{array}$ & UNCCH \\
\hline
\end{tabular}

Source: Compilation by the authors

From the tables, it can be said that, due to its interdisciplinary manner, CED programs and courses are not limited to any particular discipline, like some universities offer MBA, whereas others offer Master. Some university operate it within Business Administration department or other university lets it to operate under a different center.

Bangladeshi university stakeholders can have a look at those two tables to get an idea about the design of the program and course at their university. Also, they can check the university website (see bibliography) to jump into the detailed information.

According to Gazi (2007), Bangladesh needs well diversified education system in order to ensure sustainable community economic development. Existing academic programs in different educational institutions of the world are multidisciplinary and well diversified. For getting sustainable community economic development of Bangladesh, higher educational institutions can choose their desired course programs.

\subsection{Role of Stakeholders in Implementing CED Courses:}

The stakeholders of Bangladeshi universities who could play influential role in implementing CED courses are as follows:

1. The Ministry of Education, Bangladesh,

2. The University Grants Commission of Bangladesh,

3. The Board of Trustees (BoT) of Private Universities,

4. Students,

5. Academicians,

6. Supportive functional professionals,

7. Book publishers and distributors,

8. Employers.

Each of them has unique contribution in the educational sector of Bangladesh. They are interrelated, interdependent with each other. The ministry of education, Bangladesh is the supreme authority of the overall educational infrastructure of Bangladesh. Though, they manage universities, mainly private universities, through the University Grants Commissions of Bangladesh (UGC), but the ministerial contribution is huge. Public universities of Bangladesh are autonomous, but they are beneficiary from the government. These two governmental bodies can influence universities to design, inaugurate and execute CED courses in different levels of the educational programs. 
The Board of Trustees (BoT) of private universities own and manage the overall private university operations and they are liable to the UGC. They should assess the credibility of this course by considering the course lists provided by the researchers and hopefully they would find it lucrative in the possible inclusion of the CED course in their existing curricula or design a new program or course and employ the skilled academicians in order to run the program and course.

Students can be benefited from the CED courses by learning the sustainable and resilient contribution to the society. They may be highly interested to go for further study in reputed foreign universities in those programs. However, getting admitted and studying in any foreign university is highly challenging. If they get CED course in Bangladeshi universities, then they would stay in Bangladesh develop their career as a successful CED professional.

CED is a good research field in Bangladeshi perspectives and academicians are the leaders of any research. So, CED programs would be a great opportunity for academicians to unveil new research fields which would ultimately develop the country's community at a great extent. They can see those courses, study the course details by jumping into the website, build interest and urge their concern of possible inclusion of this course to the authorities with proper description of the pros of the CED courses.

Supportive functional professionals, like administration officers, can play a role in including this program and course at the university level. In both type of universities of Bangladesh (Public and Private), they can raise their concern along with the academicians by considering the application and popularity of this course in many reputed foreign universities.

Without book, it's not possible to deliver course properly. Both students and academicians need books related to CED. Book publishers and distributors can make those books available in the market so that academicians and students can do some self-reading for now which would urge the universities to develop courses in upcoming future.

According to Phillips and Pittman (2009), CED professional could be anybody if s/he has the required skills. Employers can demand CED skills in their job requirements, design specialized training programs for teaching this CED course to the existing employees. If they start demanding CED skill in their job requirement, then, it would motivate the universities to think, design and execute CED program and course(s) in their course curricula.

\section{LIMITATIONS, DIRECTIONS FOR FUTURE STUDY AND CONCLUSIONS}

The study was purely relied on the secondary information, that is, the respective websites. The study didn't contact any university officials who actually involved in this program. Another limitation of the study was to mention the program names and types only without mentioning its details due to huge information. However, the study suggests to visit the websites (mentioned in the bibliography) to find out the detailed information required to develop course curriculum.

There is little information about courses in Bangladeshi universities; especially the public university websites contain insufficient information. This sort of limitation hinders researchers to find out the exact scenario of the courses which offer under development studies of different Bangladeshi universities.

Future study could be an opinion survey of the stakeholders of universities of Bangladesh which would be a good implication of this study. The opinion survey could also find out the critical aspects of the CED courses mentioning its pros and cons in Bangladeshi perspectives. The study identified reasons the foreign universities offer CED courses with benefits. Future study would focus on the applicability of those enlisted benefits in Bangladesh perspectives.

Researchers wanted to include an opinion survey before but due to ongoing pandemic, it was not possible to get access to the stakeholders as on-campus study programs were totally off. However, they have the plan to conduct this survey after May 24, 2021 when the universities of Bangladesh resume their full-fledged on-campus education (Dhaka Tribune, 2021).

The study concluded that, this study is exploratory in nature and discussed relatively a new dimension of studying CED programs and courses at the university level which would ensure the sustainable development of the country. This study idea could be implemented in other country which doesn't have CED course at their university level. So, this study has a global appeal.

\section{REFERENCES}

[1] Acalog $\mathrm{ACMS}^{\mathrm{TM}}$ 2021. APEC 6700 - Regional and Community Economic Development - Acalog ACMS ${ }^{T M}$. [online] Available at: $<$ https://catalog.usu.edu/preview_course_nopop.php?catoid=12\&c oid $=87757>$ [Accessed 6 Feb. 2021].

[2] BachelorsPortal.com. 2021. Search Bachelor's Programmes Worldwide - BachelorsPortal.com. [online] Available at: $<$ https://www.bachelorsportal.com/search/\#q=kwCommunity\%20economic\%20development|lvbachelor?section=recommendations $>$ [Accessed 6 Feb. 2021].

[3] Boothroyd and Davis - 1993 - Community Economic Development Three Approaches.pdf. Available at: $<$ https://www.webpages.uidaho.edu/classbiop/pdf/tammi10/Boothroyd\&Davis_CommEconDev.pdf> [Accessed 6 Feb. 2021].

[4] Cape Breton University ,2021. Master of Business Administration in Community Economic Development (MBA in CED), Cape Breton University. [online] Available at: $<$ https://www.educations.com:0/study-abroad/cape-bretonuniversity/master-of-business-administration-in-communityeconomic-development-mba-in-ced-1296551> [Accessed 6 Feb. 2021].

[5] Cape Breton University, 2021. Master of Business Administration in Community Economic Development. [online] Cape Breton University. Available $<$ https://www.cbu.ca/academics/programs/mba-in-communityeconomic-development/> [Accessed 6 Feb. 2021]. 
[6] Concordia University, 2021a. Community Economic Development. [online] Available at: <https://www.concordia.ca/content/concordia/en/artsci/scpa/progr ams/ced-graduate-diploma.html> [Accessed 6 Feb. 2021].

[7] Dhaka Tribune, 2021. Universities to reopen in May. [online] Dhaka Tribune. Available at: <https://www.dhakatribune.com/bangladesh/education/2021/02/22 /public-universities-to-reopen-in-may> [Accessed 2 Mar. 2021].

[8] Gazi, M.A., 2007. The role of technical and vocational education in the national development of Bangladesh. [online] . Available at: 〈https://www.ijwil.org/files/APJCE_09_1_25_44.pdf>.

[9] Great Plains College n.d. $M B A$ CED_WarmanBookletSEP2020.pdf. Available at: <https://www.greatplainscollege.ca/sites/default/files/202011/MBA\%20CED_WarmanBookletSEP2020.pdf> [Accessed 6 Feb. 2021].

[10] Great Plains College, 2016. Master of Business Administration in Community Economic Development. [online] Great Plains College. Available at: <https://www.greatplainscollege.ca/programscourses/college-trades-university/master-business-administrationcommunity-economic> [Accessed 6 Feb. 2021].

[11] Haq, M. K., Arman, S.M., and Nazera, F., 2021. How Contract Farming in Poultry Industry Contribute to the Sustainable Community Economic Development of Bangladesh: A Literature Review. Journal of University of Shanghai for Science and Technology, 23(1).

[12] Harvard University, 2021. Economic Development Certificate. [online] Available at: <https://www.hks.harvard.edu/educationalprograms/executive-education/admissions-fees/executivecertificates/economic> [Accessed 6 Feb. 2021].

[13] Hassan, M.K. and Renteria-Guerrero, L., 1997. The Experience of the Grameen Bank of Bangladesh in Community Development. International Journal of Social Economics, 24, pp.1488-1523.

[14] Hossain, B., Bhuiyan, A.H., Darda, A. and Siwar, C., 2015. Prospects of Community Economy Development in Bangladesh: Experiences from Rural Communities. p.5.

[15] Illinois Institute for Rural Affairs, n.d. Comm and Econ Develop.pdf. Available at: $<$ http://wiu.edu/graduate_studies/flatsheets/Comm\%20and\%20Eco n\%20Develop.pdf> [Accessed 6 Feb. 2021].

[16] Illinois Institute of Technology 2021. Bachelor of Science in Social and Economic Development Policy < Illinois Institute of Technology. [online] Available at: <http://bulletin.iit.edu/undergraduate/colleges/scienceletters/social-sciences/bs-social-economic-developmentpolicy/\#programrequirementstext> [Accessed 6 Feb. 2021].

[17] Illinois State University, 2021b. 2020-2021 Graduate Catalog Economics | Illinois State. [online] Available at: $<$ https://illinoisstate.edu/catalog/graduate/economics/> [Accessed 6 Feb. 2021].

[18] Illinois State University, 2021a. 2020-2021 Graduate Catalog Economics | Illinois State. [online] Available at: <https://illinoisstate.edu/catalog/graduate/economics/> [Accessed 6 Feb. 2021].

[19] Islam, M., 2015. Non-governmental organizations and community development in Bangladesh. International Social Work, 60.

[20] Kansas State University, 2021. Community Development Master's Degree. [online] Available at: <https://online.kstate.edu/programs/community-development-masters/> [Accessed 6 Feb. 2021].

[21] Kansas State University, 2021. Community Development Graduate Certificate. [online] Available at: <https://online.kstate.edu/programs/certificates/graduate-certificates/communitydevelopment.html> [Accessed 6 Feb. 2021].

[22] Lawson, G. and Myers, J.E., 2011. Wellness, Professional Quality of Life, and Career-Sustaining Behaviors: What Keeps Us Well? Journal of Counseling \& Development, 89(2), pp.163-171.

[23] Lehker, T. and Furlong, J.S., 2006. Career services for graduate and professional students. New Directions for Student Services, 2006(115), pp.73-83.
[24] Massachusetts Institute of Technology ,2021. Introduction to Housing, Community, and Economic Development. [online] MIT OpenCourseWare. Available at: <https://ocw.mit.edu/courses/urban-studies-and-planning/11-401introduction-to-housing-community-and-economic-developmentfall-2015/> [Accessed 6 Feb. 2021].

[25] MastersPortal.com, 2021. Search Master's Programmes Worldwide - MastersPortal.com. [online] Available at: $<$ https://www.mastersportal.com/search/\#q=kw-

Community\%20and\%20Economic\%20Development|lv-master|tcEUR\&start=90> [Accessed 6 Feb. 2021].

[26] McClenaghan, P., 2000. Social Capital: Exploring the theoretical foundations of community development education. British Educational Research Journal, 26(5), pp.565-582.

[27] Murdoch University, 2021. Master of Community Development. [online] Available at: <https://www.murdoch.edu.au/study/courses/postgraduate/m1212 $>$ [Accessed 6 Feb. 2021].

[28] Phan, D.S., n.d. Master of Science in Community and Economic Development Akamai University. p.19.

[29] Phillips and Pittman - 2009 - An introduction to community development.pdf. Available at: <http://www.lcwu.edu.pk/ocd/cfiles/Home\%20Economics/Maj/H. Eco-204/Book-An-Introduction-to-Community-

Development.pdf\#page $=32>$ [Accessed 6 Feb. 2021].

[30] Postgrad.com 2021. 68 Postgraduate Courses for Community Development in Europe | Postgrad.com. [online] Available at: $<$ https://www.postgrad.com/courses/communitydevelopment/europe/> [Accessed 5 Feb. 2021].

[31] Ritsumeikan University, 2021. Program Structure | Master's Program in Economic Development | Graduate School of Economics | Ritsumeikan University. [online] Available at: <http://www.ritsumei.ac.jp/gsec/mped/program/> [Accessed 6 Feb. 2021].

[32] Rottinghaus, P.J., Day, S.X. and Borgen, F.H., 2005. The Career Futures Inventory: A Measure of Career-Related Adaptability and Optimism. Journal of Career Assessment, 13(1), pp.3-24.

[33] Ryerson University, 2021. The Chang School of Continuing Education - Ryerson University. [online] The Chang School of Continuing Education - Ryerson University. Available at: <https://continuing.ryerson.ca> [Accessed 6 Feb. 2021].

[34] Shaffer, R., Deller, S. and Marcouiller, D., 2006. Rethinking Community Economic Development. Economic Development Quarterly, 20(1), pp.59-74.

[35] South Dakota State University, 2021. Certificate in Community Development. [online] South Dakota State University. Available at: $\quad<$ https://www.sdstate.edu/continuing-distanceeducation/certificate-community-development> [Accessed 6 Feb. 2021].

[36] South Dakota State University, 2021. Certificate in Native Community and Economic Development. [online] South Dakota State University. Available at: $<$ https://www.sdstate.edu/continuing-distanceeducation/certificate-native-community-and-economicdevelopment> [Accessed 6 Feb. 2021].

[37] SUNY Empire State College 2021. M.A. in Community and Economic Development | School for Graduate Studies | SUNY Empire State College. [online] Available at: $<$ https://www.esc.edu/graduate-studies/graduate-degrees/graduateliberal-arts-and-science-programs/ma-community-economicdevelopment/> [Accessed 6 Feb. 2021].

[38] SUNY Empire State College, 2021. M.A. in Community and Economic Development | Advanced Certificate Options | School for Graduate Studies | SUNY Empire State College. [online] Available at: <https://www.esc.edu/graduate-studies/graduatedegrees/graduate-liberal-arts-and-science-programs/macommunity-economic-development/advanced-certificate-options/> [Accessed 6 Feb. 2021].

[39] The Borgen Project 2018. 10 Facts About BRAC, the World's Largest NGO. [online] The Borgen Project. Available at: 
<https://borgenproject.org/10-facts-about-brac/> [Accessed 5 Feb. 2021].

[40] The Open University Of Tanzania n.d. Bachelor of Community Economic Development (BCED) - The Open University Of Tanzania. Available at: <https://www.out.ac.tz/bced/> [Accessed 6 Feb. 2021].

[41] The Pennsylvania State University 2021. Curriculum and Course Requirements. [online] Plone site. Available at: <https://aese.psu.edu/graduate/cedev/masters/curriculum> [Accessed 6 Feb. 2021].

[42] The Pennsylvania State University 2021. Graduate Certificate Requirements. [online] Plone site. Available at: $<$ https://aese.psu.edu/graduate/cedev/graduate-certificateprogram/graduate-certificate-requirements $>$ [Accessed 6 Feb. 2021].

[43] The Pennsylvania State University 2021. Graduate Certificate. [online] Plone site. Available at: $<$ https://aese.psu.edu/graduate/cedev/graduate-certificateprogram> [Accessed 6 Feb. 2021].

[44] The University Of North Carolina At Chapel Hill, 2021. Course List. [online] Available at: 〈https://mpa.unc.edu> [Accessed 6 Feb. 2021].

[45] The University Of North Carolina At Chapel Hill, 2021. Degree Requirements. [online] Available at: <https://mpa.unc.edu> [Accessed 6 Feb. 2021].

[46] University College of the North, 2021b. Community Economic Development. [online] Available at: <https://www.ucn.ca/sites/academics/facultyarts/programofferings /cb/Pages/Community-Economic-Development.aspx > [Accessed 6 Feb. 2021].

[47] University Grants Commission of Bangladesh, 2021a. List of Private Universities | University Grants Commission of Bangladesh. [online] List of Private Universities | University Grants Commission of Bangladesh. Available at: <http://www.ugc-universities.gov.bd/private-universities> [Accessed 5 Feb. 2021].
[48] University Grants Commission of Bangladesh, 2021b. List of Public Universities | University Grants Commission of Bangladesh. [online] List of Public Universities | University Grants Commission of Bangladesh. Available at: <http://www.ugc-universities.gov.bd/public-universities> [Accessed 5 Feb. 2021].

[49] University of Central Arkansas, 2021. Master of Science in Community and Economic Development - Geography. [online] Available at: <https://uca.edu/geography/msced/> [Accessed 6 Feb. 2021].

[50] University of Central Arkansas, 2021. Postgraduate courses | Postgrad Course Search | Postgrad.com. [online] Available at: <https://www.postgrad.com/> [Accessed 5 Feb. 2021].

[51] University of New Hampshire, 2021. Community Development Policy and Practice (M.A.) < University of New Hampshire. [online] Available at: <https://catalog.unh.edu/graduate/programsstudy/community-development-policy-practice/communitydevelopment-policy-practice-ma/> [Accessed 6 Feb. 2021].

[52] University of Waterloo, 2016. Certificate in Economic Development. [online] Economic Development Program. Available at: <https://uwaterloo.ca/economicdevelopment/certificate-economic-development> [Accessed 6 Feb. 2021].

[53] Victoria University, 2021. Master of International Community Development. [online] Victoria University | Melbourne Australia. Available <https://www.vu.edu.au/courses/international/AMCD> [Accessed 6 Feb. 2021].

[54] Weissbourd et al. - MARKET-BASED COMMUNITY ECONOMIC DEVELOPMENT.pdf. Available at: <http://rw-ventures.com/wpcontent/uploads/2017/01/Market-Based-Development.pdf> [Accessed 6 Feb. 2021].

[55] Western Illinois University, 2021. Core Courses - Western Illinois University. [online] Available at: $<$ http://wiu.edu/IIRA/community_and_economic_development/co urses.php> [Accessed 6 Feb. 2021]. 